\title{
International Handbook of Research
}

\section{on Teachers and Teaching}

\section{Part One}

\section{Editors}

Lawrence J. Saha

Australian National University, Australia

\section{A. Gary Dworkin}

University of Houston, USA

\section{Springer}




\section{International Handbook of Research on Teachers and Teaching}

\section{Part Two}

\section{Editors}

\section{Lawrence J. Saha}

Australian National University, Australia

A. Gary Dworkin

University of Houston, USA

Springer 


\section{Editors}

Lawrence J. Saha

Australian National University

Canberra, Australia

lawrence.saha@anu.edu.au
A. Gary Dworkin

University of Houston

Houston, USA

gdworkin@uh.edu

Library of Congress Control Number: PCN applied for

C 2009 Springer Science+Business Media, LLC

All rights reserved. This work may not be translated or copied in whole or in part without the written All rights reserved. This work permission of the publisher (Springer Science + Business Media, LLC, 233 Spring Street, New 10013 , USA), except for brief excerpts in connection with reviews or scholarly analysis. Use in connection with any form of information storage and retrieval, electronic adaptation, comp

or dissimilar methodology now known or hereafter developed is forbidden. The use in this publication of trade names, trademarks, service marks, and similar terms, even if they are not identified as such, is not to be taken as an expression of opinion as to whether or nothey are subject to proprietary rights.

Printed on acid-free paper

987654321

springer.com 
Springer International Handbook of Research on Teachers and Teaching

VOLUME 21

A list of titles in this series can be found at the end of this volume. 


\section{CONTENTS}

\section{Part One}

Tntroduction to the Handbook

1 Introduction: New Perspectives

on Teachers and Teaching

Lawrence J. Saha and A. Gary Dworkin

Section 1 Introduction to the Study of Teachers

2 Teachers in History

W. Robert Houston

3 Trends in Research on Teaching:

An Historical and Critical Overview

Margaret D. LeCompte

4 Teacher Research and Teacher as Researcher

Cheryl J. Craig

5 The Dissemination of Knowledge about Research on Teachers, to the Teachers

Lawrence J. Saha

6 Social Science Theories on Teachers, Teaching, and $\mathbb{E d u c a t i o n a l ~ S y s t e m s ~}$

Jeanne H. Ballantine and Joan Z. Spade 
7 Developments in Quantitative Methods in Research into Teachers and Teaching

John P. Keeves and I Gusti Ngurah Darmawan

Section 2 Becoming a Teacher

8 Teacher Preparation Programs

Kathryn M. Borman, Elaine Mueninghoff, Bridget A. Cotner, and Phyllis Bach Frederick

9 Teacher Certification and Credentials:

From a Focus on Qualification to a Commitment to Performance

Scott Imig, Stephen Koziol, Virginia Pilato, and David Imig

10 The Continuing Education of Teachers: In-Service Training and Workshops

Robert V. Bullough, Jr

11 The Role of Mentors of Preservice and Inservice Teachers Jo Blase

12 The Lifelong Learning Issue: The Knowledge Base Under Professional Development?

Bruce Joyce, Jim Wolf, and Emily Calhoun

Section 3 The Characteristics of Teachers

13 The Status and Prestige of Teachers and Teaching

Linda Hargreaves

14 The Political Orientations of Teachers

Mark B. Ginsburg and Sangeeta G. Kamat

15 Dimensions of Quality in Teacher Knowledge

Michael J. Lawson, Helen Askell-Williams,

and Rosalind Murray-Harvey

16 Teachers'Values in the Classroom

Clodie Tal and Yoel Yinon 
17 Footnotes to Teacher Leadership Mark A. Smylie and David Mayrowetz

18 Sex Segregation and Tokenism Among Teachers Barbara J. Bank

19 The Classroom as an Arena of Teachers' Work Margaret Freund

201 Teachers and Democratic Schooling Thomas Kwan-Choi Tse

21 Teachers and Parents

Mavis G. Sanders

22 Teacher Commitment

Nordin Abd Razak, I Gusti Ngurah Darmawan, and John P. Keeves

23 Teachers' Beliefs About Student Learning and Motivation

24 Teachers and the Politics of History School Textbooks Joseph Zajda

25 'Teachers' Emotion Regulation

Rosemary E. Sutton and Elaine Harper

26 Principal and Teachers Relations: Trust at the Core of School Improvement

Pamela R. Hallam and Charles Hausman

27 Teacher Misbehaviour

Ramon (Rom) Lewis and Philip Riley

28 School Administrator Mistreatment of Teachers

Joseph Blase 
Section 5 Teacher Life-Cycles

29 Tracking Teachers

Sean Kelly

30 Teachers'.Work, Power and Authority

Terri Seddon and Phoebe Palmieri

31 Teachers as Professionals: Salaries, Benefits and Unions

Nina Bascia

32 Teacher Burnout and Teacher Resilience: Assessing the Impacts of the School Accountability Movement A. Gary Dworkin

33 Teachers and Promotion: Research Evidence on the Role of Gender, Career Intentions, Promotion Criteria and Teacher Satisfaction

Ping-Man Wong

Section 6 Teachers and Teaching in Comparative Perspective

34 Teachers in Comparative Perspective Anthony Clarke

35 Comparative Perspectives on Teachers, Teaching and Professionalism

Mark B. Ginsburg and Nagwa M. Megahed

36 Teachers and Teaching in Eastern and Western Schools: A Critical Review of Cross-Cultural Comparative Studies Yanping Fang and S. Gopinathan

37 Teachers and Teaching in Africa

Lawrence Chi.Awasom

38 Greek Cypriot Teachers and Classroom Diversity:

Intercultural Education in Cyprus

Elena Papamichael 


\section{Part Two}

\section{Section 7 Dimensions of Teaching}

39 Three Sides of Teaching: Styles, Models, and Diversity Bruce Joyce and Emily Calhoun

40 Creating Productive Learning Environments in Culturally Pluralistic Classrooms

Revathy Kumar and Stuart A. Karabenick

$\Delta 1$ Justice in Teaching

Nura Resh and Clara Sabbagh

42. Ethics and Teaching

Clara Sabbagh

43 Teacher Expectations and Labeling

Christine Rubie-Davies

Section 8 Teaching in Classrooms

44 Teacher-Student Interaction

Joshua M. Englehart

45 Assessment and Examinations

Susan M. Brookhart

46 Classroom Management

Barbara Landau

47 Teachers as Role Models

Wayne Martino

Kerri Ullucci

49 Teaching in Large and Small Classes 
50 Teaching and Learning in the ICT Environment

Bronwen Cowie and Alister Jones

51 Effective Teaching: An Emerging Synthesis

Thomas L. Good, Caroline R. H. Wiley, and Ida Rose Florez

52 Teaching and Nonverbal Behavior in the Classroom Elisha Babad

Section 9 Teaching Specific Student Populations

53 Teaching at the Secondary Level

Floyd M. Hammack and Dana M. Grayson

54 Teaching at Tertiary Level

Linda Hort

55 Teaching for Technical and Vocational Education and Training (TVET)

Hugh Guthrie, Roger Harris, Michele Simons, and Tom Karmel

56 Teaching Students with Special Needs

Bruce Allen Knight

57 Teaching Gifted and Talented Children

Martina Endepohls-Ulpe

58 Teaching "at risk" Students: Meeting Their Needs Ramon Lewis and.Tricia McCann

59 Teaching Indigenous Populations Rodney A. Clifton

60 Single-Sex or Coeducational Classes Peter W. Cookson, Jr.

61 Teaching and the Boy Problem Rob Gilbert 
2 The Teaching of Reading

Barbara R. Foorman and Kristi L. Santi

63 Teaching History

Joseph Zajda and John A. Whitehouse

64 Teaching Mathematics

Michael L. Connell

65 Teaching Science

John P. Keeves and I Gusti Ngurah Darmawan

66: Teaching About Political and Social Values

1001 Murray Print

67 Conditions for Promoting Moral and Prosocial Development in Schools

Alan J. Reiman

68 Teaching a Second Language

Sharon H. Ulanoff

69 Teaching in Arts Education Peter Wright

70 Research on Teaching Health and Physical Education John R. Todorovich

Section 11 Great Debates about Teachers and Teaching

71 Keeping Track or Getting Offtrack: Issues in the Tracking of Students

Lynn M. Mulkey, Sophia Catsambis, Lala Carr Steelman, and Melanie Hanes-Ramos

72 High Stakes Testing and Teaching to the Test Gary Natriello 
73 Value-Added Models of Teacher $\mathrm{Effects}$ Pamela F. Tobe

74 Teachers and Teaching During Educational Restructuring and Reforms

Patrick J.W. MCGinty

75 Grade Retention Redux: A Dissenting Perspective Jon Lorence

76 Teachers and Teaching in an Era of Heightened School Accountability: A Forward Look Lawrence J. Saha and A. Gary Dworkin

Name Index (Vol_I)

Subject Index (Vol_l)

Contributors

Name Index (Vol_II)

Subject Index (Vol_II) 


\title{
CONTRIBUTORS
}

\author{
Nordin Abd Razak \\ School of Education, Universiti Sains Malaysia, Malaysia, norazak@usm.my \\ Helen Askell-Williams \\ School of Education, Flinders University, Adelaide, Australia, \\ helen.askell-williams@flinders.edu.au
}

Lawrence C. Awasom

Department of Social Sciences - Anthropology, Houston Community College Northeast, The University of Houston, Pinemont, Houston, TX 77018, lawasomwalere@yahoo.com or Lawrence.awasom@hccs.edu

\section{Elisha Babad} School of Education, Hebrew University of Jerusalem, Mt. Scopus, Jerusalem
91905, Israel, Elisha@vms.huji.ac.il

Jeanne Ballantine

Sociology and Anthropology College of Liberal Arts, Wright State University, Dayton, OH 45435, jeanne.ballantine@wright.edu

\section{Barbara J. Bank}

University of Missouri, Columbia, MO 65211, bankb@missouri.edu

\section{Nina Bascia}

Ontario Institute for Studies in Education of the University of Toronto, Toronto, ON, Canada M5S 1V6, nina.bascia@utoronto.ca

\section{Jo Blase}

Department of Educational Leadership, College of Education,

The University of Georgia, Athens, GA 30602, jblase@uga.edu 
Joseph Blase

College of Education, The University of Georgia, Athens, GA 30602,

blase@uga.edu

\section{Peter Blatchford}

Department of Psychology and Human Development, Institute of Education, University of London, London WC1H 0AA, UK., p.blatchford@ioe.ac.uk

\section{Kathryn M. Borman}

Alliance for Applied Research in Education and Anthropology, Department of Anthropology, University of South Florida, Tampa, FL 33620, kborman@cas.usf.edu

\section{Susan M. Brookhart}

Center for Advancing the Study of Teaching \& Learning, School of Education, Duquesne University, Pittsburgh PA 15282, susanbrookhart@,bresnan.net

\section{Penelope Brown}

Department of Psychology and Human Development, Institute of Education, University of London, London WC1H 0AA, UK, p.brown@ioe.ac.uk

Robert V. Bullough, Jx.

Center for the Improvement of Teacher Education and Schooling, Brigham Young University, Provo, UT 84602,Bob_Bullough@,BYU.Edu

\section{Emily Calhoun}

The Phoenix Alliance, St. Simons Island, GA 31522,EFCPhoenix@aol.com

\section{Sophia Catsambis}

Queens College and Graduate Center, City University of New York, NY 10075, sophia@troll.soc.qc.edu

\section{Andrea Christensen}

Department of Psychology, University of Notre Dame, Notre Dame, IN, Christensen.26@nd.edu

\section{Anthony Clarke}

Faculty of Education, University of British Columbia, Vancouver, BC, Canada V6T1Z4, anthony.clarke@ubc.ca

\section{Rodney A. Clifton}

Faculty of Education, St. John's College, University of Manitoba, Winnipeg, Manitoba, Canada R3T 2M5, Clifton@MS.UManitoba.ca

Michael L. Connell

Department of Curriculum and Instruction, College of Education, University of Houston, Houston, TX 77204, MKahnl@aol.com 
Peter W. Cookson, Jr.

Lewis \& Clark College, Graduate School of Education \& Counseling, Portland,
OR 97219, cookson@lclark.edu

\section{Bridget A. Cotner} Alliance for Applied Research in Education and Anthropology, University of South
Florida, Tampa, FL, bcotner@cas.usf.edu

\section{Bronwen Cowie}

Centre for Science and Technology Education Research, University of Waikato

Hamilton, New Zealand, b.cowie@waikato.ac.nz

\section{Cheryl Craig}

Department of Curriculum and Instruction, University of Houston, Houston, TX
77204, ccraig@uh.edu

\section{Gusti Ngurah Darmawan} School of Education, The University of Adelaide, Adelaide, Australia,
igusti.darmawan@adelaide.edu.au

\section{A. Gary Dworkin}

Department of Sociology, University of Houston, Houston, TX,
gdworkin@mail.uh.edu

Martina Endepohls-Ulpe

Institut für Psychologie, Universität Koblenz-Landau, Campus Koblenz,

Universitätsstraße 1, 56070 Koblenz, Germany, endepohl@uni-koblenz.de

Joshua M. Englehart

Riverside High School, Painesville, OH 44077,pa_englehart@lgca.org

Yanping Fang

Centre for Research in Pedagogies and Practices, National Institute of Education, Nanyang Technological University, Singapore 637616, yanping.fang@nie.edu.sg

\section{Ida Rose Florez}

Educational Psychology, College of Education, Graduate College

University of Arizona, Tucson, AZ 85721,irflorez@email.arizona.edu

Barbara R. Foorman

Florida Center for Reading Research, Florida State University, Tallahassee,
FL 32301, bfoorman@fcrrorg

Phyllis Bach Frederick

University of Cincinnati, Department of Education, Clermont College,

University of Cincinnati, Batavia, OH, frederpb@adelphia.net 
Margaret Freund

Professional Community Identity and Social Justice, School of Education,

University of South Australia, Mawson, Lakes Campus 5095, Australia, Margaret. Freund@unisa.edu.au

Rob Gilbert

School of Education, The University of Queensland, St Lucia, Queensland 4072 , Australia, Rob.Gilbert@uq.edu.au

Mark B. Ginsberg

Academy for Educational Development, Washington, DC 20009,

mginsburg49@yahoo.com

Thomas L. Good

Educational Psychology, College of Education, University of Arizona, Tucson, AZ 85721,goodt@u.arizona.edu

\section{S. Gopinathan}

Centre for Research in Pedagogies and Practices, National Institute of Education, Nanyang Technological University, Singapore 637616, Gopinathan.S@nie.edu.sg

Dana M. Grayson

Department of Humanities and the Social Sciences, New York University, NY10003,fmh1@nyu.edu

Hugh Guthrie

National Centre for Vocational Education Research, Adelaide, SA 5000, Australia, hugh.guthrie@ncver.edu.au

\section{Pamela R. Hallam}

Educational Leadership and Foundations 306 MCKB, Brigham Young University, Provo, UT 84602, pam_hallam@byu.edu

Floyd M. Hammack

Department of Humanities and the Social Sciences, New York University, NY10003,fmh1@nyu.edu

\section{Melanie Hanes-Ramos \\ University of South Carolina, Beaufort, SC, hanesml@gwm.sc.edu}

\section{Linda Hargreaves}

Faculty of Education, University of Cambridge, Cambridge,UK, 1h258@cam.ac.uk

Elaine Harper

Office of Doctoral Studies, Cleveland State University, Cleveland, OH 4.115, e.harper@csuohio.edu 
Roger Harris

Centre for Research in Education, Equity and Work, University of South Australia,

Mawson Lakes, SA 5095, Australia, roger.harris@unisa.edu.au

\section{Charles Hausman} Educational Leadership Studies, University of Kentucky, Lexington, KY 40506,
charles.hausman@uky.edu

\section{Linda Hort}

CEDAM, The Australian National University, Canberra, ACT 0200, Australia, Linda.Hort@anu.edu.au

\section{W. Robert Houston}

Department of Curriculum and Instruction, Institute for Urban Education at the University of Houston, Houston, TX, rhouston@uh.edu

\section{David Imig}

Department of Curriculum and Instruction, College of Education, University of Maryland, College Park, MD 20742, dimig@umd.edu

\section{Scott Imig}

Watson School of Education, University of North Carolina Wilmington,

Wilmington, NC 28403, imigs@uncw.edu

\section{Alister Jones}

School of Education, University of Waikato, Hamilton, New Zealand, a.jones@waikato.ac.nz

\section{Bruce Joyce}

Booksend Laboratories, St. Simons Island, GA 31522, brjoyce@worldnet.att.net

\section{Sangeeta G. Kamat}

Department of Educational Policy Research and Administration, University of Massachusetts-Amherst, South Amherst,MA 01003, skamat@educ.umass.edu

Stuart A. Karabenick

Department of Psychology, University of Michigan, Ypsilanti, MI 48197, stuart.karabenick@emich.edu

\section{Tom Karmel}

National Centre for Vocational Education Research, Station Arcade, Adelaide, SA 5000, Australia, tom.karmel@ncver.edu.au

John P. Keeves

School of Education, The University of Adelaide, Adelaide, Australia, john.keeves@adelaide.edu.au 
Sean Kelly

Center for Research on Educational Opportunity, Notre Dame, IN 46556, Kelly.206@nd.edu

Bruce Allen Knight

Research \& Innovation, Faculty of Arts, Humanities \& Education, Central Queensland University, Mackay, MC 4741, Australia, b.knight@cqu.edu.au

\title{
Stephen Kóziol
}

Department of Curriculum and Instruction (EDCI), College of Education, University of Maryland, College Park, MD 20742, skoziol@umd.edu

\section{Revathy Kumar}

Judith Herb College of Education, The University of Toledo, Toledo, OH 43606, RKumar@UTNet.UToledo.Edu

\section{Barbara Landau}

College of Education, University of Hawaii, Honolulu, HI 96822, blandau@hawaii.edu

\section{Michael J. Lawson}

Centre for the Analysis of Educational Futures, School of Education, Flinders University, Adelaide, Australia, mike.lawson@flinders.edu.au

\section{Margaret D. LeCompte}

School of Education, University of Colorado, Boulder, CO 80309, Margaret.

Lecompte@,colorado.edu

\section{Ramon Lewis}

Faculty of Education, La Trobe University, Bundoora 3086, VIC, Australia, r.lewis@latrobe.edu.au

\section{Jon Lorence}

Department of Sociology, The University of Houston, Houston, TX 77204, jlorence@mail.uh.edu

\author{
Wayne J. Martino \\ Faculty of Education, The University of Western Ontario, London, ON, Canada \\ N6G1G7,wmartino@uwo.ca
}

David Mayrowetz

Policy Studies, College of Education, University of Illinois at Chicago, Chicago, IL 60607 dmayro@uic.edu

\section{Tricia McCann}

Faculty of Education, La Trobe University, Bundoora 3086, Australia, P.McCann@latrobe.edu.au 
Patrick J. W. McGinty

Department of Sociology and Anthropology, Western Illinois University, Macomb, IL 61455, PJ-McGinty@wiu.edu

Nagwa M. Megahed

Monitoring and Evaluation Division, Education Reform Program, Maadi, Cairo,Egypt, nmegahed@equipegypt.org

Debra K. Meyer

Department of Education, Elmhurst College, Elmhurst, IN, debram@elmhurst.edu

\section{Elaine Mueninghoff}

Department of Education, Clermont College, University of Cincinnati, Batavia, OH, muenine@uc.edu

Lynn M. Mulkey

University of South Carolina, Beaufort, Bluffton, SC 29909, mulkey@sc.edu

Rosalind Murray-Harvey

School of Education, Flinders University, Adelaide, Australia, roz.murray-harvey@flinders.edu.au

Gary Natriello

Teachers College, Columbia University, NY 10027,gjn6@columbia.edu

Phoebe Palmieri

Faculty of Education, Monash University, Clayton, VIC 3800, Australia, p.palmieri@optusnet.com.au

Elena Papamichael

Institute of Education, University of London, London WC1N 2AB, UK, epapamichael@gmail.com

Virginia Pilato

Division of Certification and Accreditation, Maryland State Department of Education, Baltimore, MD 21201,vpilato@msde.state.md.us

Murray Print

Faculty of Education and Social Work, University of Sydney, Sydney, NSW 2006, Australia, m.print@edfac.usyd.edu.au

\section{Alan J. Reiman}

Department of Curriculum and Instruction, College of Education, North Carolina State University, Raleigh, NC 27695, ajreiman@gwced.ncsu.edu 


\section{Nura Resh}

School of Education, Hebrew University of Jerusalem, Mount Scopus, Jerusalem 91905, Israel,msnura@mscc.huji.ac.i1

Philip Riley

Faculty of Education, Monash University, Melbourne, VIC, Australia, Philip.riley@education.monash.edu.au

Christine Rubie-Davies

School of Teaching, Learning and Development, Faculty of Education, The University of Auckland, Auckland, New Zealand, c.rubie@auckland.ac.nz

\section{Anthony Russell}

Department of Psychology and Human Development, Institute of Education, University of London, London WC1H 0AA, UK, a.russel1@ioe.ac.uk

\section{Clara Sabbagh}

Faculty of Education, University of Haifa, Mount Carmel, Haifa 31905, Israel, csabbagh@construct.haifa.ac.il

\section{Lawrence J. Saha}

School of Social Sciences, Faculty of Arts, The Australian National University, Canberra, ACT 0200, Australia, Lawrence.Saha@anu.edu.au

\section{Mavis G. Sanders}

Teacher Development and Leadership, Johns Hopkins University, Columbia, MD 21046,msanders@jhu.edu

\section{Kristi L. Santi}

The Santi Group, Houston, TX 77225, kristi@thesantigroup.com

Terri Seddon

Faculty of Education, Monash University, Clayton, VIC 3800, Australia, Terri.Seddon@Education.monash.edu.au

\section{Michele Simons}

School of Education, University of South Australia, Mawson Lakes, SA 5095, Australia, michele.simons@unisa.edu.au

Mark A. Smylie

College of Education, University of Illinois at Chicago, Chicago, IL 60607, smylie@uic.edu

Joan Z. Spade

Department of Sociology, State University of New York, Brockport, NY 14420, jspade@brockport.edu 
Lala Carr Steelman

Department of Sociology, University of South Carolina, Columbia, SC 29208,
steelman@.sc.edu

Rosemary E. Sutton

Cleveland State University, Department of Curriculum and Foundations, Cleveland,
OH 44115, r.sutton@csuohio.edu

Clodie Tal

Levinsky College.of Teachers' Education, Tel Aviv 61490, Israel,
clodietal@gmail.com

Pamela Tobe Sociology of Education Research Group, Department of Sociology, University of
Houston, TX 77204, pftobe@comcast.net

John R. Todorovich

Department of Health, Leisure, and Exercise Science, University of West Florida,

Pensacola, FL, jtodorovich@uwf.edu

Thomas Kwan-Choi Tse

Faculty of Education, The Chinese University of Hong Kong, Shatin, N.T.,

Julianne C. Turner

Department of Psychology, University of Notre Dame, Notre Dame, IN,
jturner3@nd.edu

Jim Wolf

The Phoenix Alliance, St. Simons Island, GA 31522

\section{Sharon H. Ulanoff}

Charter College of Education, Curriculum and Instruction, California State

University, Los Angeles, CA 90032, sulanof@exchange.calstatela.edu

\section{Kerri Ullucci} Dartmouth Education Department, University of Massachusetts, North Dartmouth,
MA 02747, kullucci@umassd.edu

John A. Whitehouse

Melbourne Graduate School of Education, The University of Melbourne, VIC 3010,
Australia, j.whitehouse@unimelb.edu.au

Caroline R. H. Wiley

Educational Psychology, College of Education, Graduate College, University of Arizona, Tucson, AZ 85721, crhummel@email.arizona.edu 


\title{
Ping-Man Wong
}

Department of Educational Policy and Administration, Hong Kong Institute of Education, Tai Po, N.T., Hong Kong, pmwong@ied.edu.hk

Peter Wright

School of Education, Murdoch University, Murdoch, Western Australia 6150, Australia, p.wright@murdoch.edu.au

\author{
Yoel Yinon \\ Department of Psychology, Bar-Ilan University, Ramat Gan 52900, Israel, \\ Yinony@mail.biu.ac.il
}

\section{Joseph Zajda}

Trescowthick School of Education, Melbourne Campus, Australian Catholic University, Fitzroy, VIC 3065, Australia, j.zajda@patrick.acu.edu.au 


\section{THE DISSEMINATION OF KNOWLEDGE ABOUT RESEARCH ON TEACHERS, TO THE TEACHERS}

\section{Lawrence J. Saha}

\section{Introduction}

The purpose of this chapter is to examine the extent to which research knowledge about teachers, and for teachers, is actually disseminated in a way that enhances the teaching profession, the teachers themselves and the practice of teaching. Teachers occupy a position of direct contact with the students that not only they, but the entire educational system serves. They are at the bottom of a Y-chain of professionals that includes academic researchers on the one side of the $Y$, and educational administrators on the other. The former have no authority over teachers, but engage in research activity that can help them more effectively discharge their professional duties and use their professional expertise. The latter are in a chain of authority which defines and regulates their roles in the classroom. Thus on the one hand, school teachers are the object of much potentially useful academic research, but on the other they are increasingly accountable to administrators who have financial, organizational and community responsibilities.

In the best of all possible worlds, the dissemination of "useful" research knowledge to teachers goes through the administrators, and is supported by them. However, it can happen that the research is not deemed useful, or is simply not transmitted. Finally, it occasionally happens that the teachers themselves are researchers and create their own useful knowledge which enhances the performance of their classroom roles and responsibilities.

In the following chapter, I will examine our current state of knowledge about the links between research knowledge and the classroom teacher. I will focus on the production of academic research knowledge and its accessibility to the teacher. I will also examine what we know about education administrators and how they serve as conduits of that knowledge to the teacher. Finally I will focus on the teachers themselves as producers of research knowledge. 
Research on Teachers and Teaching - Usefulness and Accessibility

No one can deny the amount of funding, production of, and publication of educational research which focuses on teachers. But what is more important, there have been long-standing debates both within and outside of academic and research circles which have questioned the usefulness of this research. As Bidde an educational research generally, documented, there has been a history of ademics (Finn, 1988; Hemsley-Brown \& Sharp, 2003; Sroufe, 1997).

The basic argument has been that educational research has produced little useful knowledge for the improvement of educational outcomes, and that as a result considerable research funding has been wasted. However, as a result of their interviews with school principals in both the United States and Australia, Biddle and Saha $(2002 / 2005)$ found that the findings from educational research do reach school principals, and many principals do take this research into account many principals pass decisions in running their schools. Furthermore they found the mords, there on their own exposure to research knowe knowledge is useful, and does make a differis evidence that educational res always direct manner. Some principals play a direct role, while others play a more indirect role.

But there were other aspects in the findings of Biddle and Saha $(2002 / 2005)$ that are relevant for our concern here. They found that some principals take a more active role in both generating and discovering research by establishing committees in their own schools to conduct research, by speaking about research to other principals, by visiting schools which had implemented research-based policies, and by finding out about it at conferences (Biddle \& Saha, 2006). However, it seems that these roles of the principal are enhanced when they have teachers in their schools who are more highly trained and who can assist in the generation of research knowledge (Saha, Biddle, \& Anderson, 1995). What seems to be ideal is when schools develop a secific problems. research knowledge is generated and unnovativeness and effectiveness of schools Principals are key persons in the innovative principal is one who is more (Hallinger, 2003). Furthermore, the in also enthusiastic about innovation (Saha \& collaborative and consultative, and is also ensul approach to innovative leadership is Biddle, 2006). Underlying this more successte in school educational policy. In their an appreciation of research and its importance ind that $70 \%$ of both American and study of school principals, Biddle and Saha fould know to be usually of value or Australian school principals considered research knowledge was of little or no value: invaluable, and less than $10 \%$ thought reser the be Furthermore, $56 \%$ of Australians and (Biddle \& Saha, 2002/2005).

(he school level and at

Thus it is clear that academic research know least to the level of the principal, and is appreciated through the decisions of the principal? reach the average teacher in any way other than the more effective schools? Clearly, Furthermore does this research knowledge contribute to more effective schools? Clealy 
this is a question which focuses on the relationship between school principals and, to a large extent, to the relationships between the school principals and their teachers. In many ways, this relationship depends on the style of leadership exercised by principals.

\section{Education Research Knowledge, School Principals and Teachers}

All too often the main criterion of the successful school principal is student achievement. Schools where students perform well are assumed to be led by excellent principals. However it is the teachers in the classroom, and the ways they carry out their own teaching roles that largely determine student achievement. In the end, it is the relationship between the school principal and the teachers, and the type of leadership that the school principal provides, which will determine how well the teachers and the students perform. Already in the 1990s, movements were occurring in the United States and elsewhere to introduce greater accountability from principals and teachers for student performance (Daresh, 1998). Indeed, the current demands of the No Child Left Behind Act (United States, 2002) in the United States requires that schools be staffed with high quality teachers, and of course this will depend largely on the principal.

Most would agree that the principal's responsibilities of running a school include financial and maintenance duties, and most would agree that matters relating to the curriculum, staff supervision, staff development, and the maintenance of an academic-oriented school climate also fall within these responsibilities. In a study of 325 middle level principals and teachers, O'Donnell and White (2005) found a number of factors which teachers perceived as influencing student achievement in mathematics and reading scores, the most important being the promotion of a learning environment. But what is more unusual about their findings are the implications for the principal: In order to foster a learning school climate, O'Donnell and White present Hallinger's (1987) list of the principal's functions, one of which is to promote the professional development of teachers. This function includes attending, developing and leading instruction-based activities for teachers. What this implies is that the principal, himself or herself, must be up-to-date on relevant research knowledge, and in the process of maintaining a learning school climate, must pass on that knowledge to teachers. Unfortunately, a recent study found that principals often are not adequately prepared for this task, which implicitly means that they might not have adequate familiarity with the relevant research knowledge about educational structures and processes (Petzko et al., 2002).

Another somewhat different example of the principal's function in transmitting research knowledge to the teachers is found in the study by Dworkin, Saha, and Hill (2003) of 2961 urban public school teachers in Texas. In focusing on teacher buinout and the leadership style of the school principal, Dworkin and his colleagues found that teacher burnout was lowest in schools where the teachers perceived the school climate as more "democratic". Being "democratic" meant that the teachers participated more in the decision-making processes of the school, and had access to thowledge related to the school's full operation. In this "democratic" environment, reteachers also enjoyed the support of the principal in their day-to-day classroom 
experiences. Implicit in this finding is that the inclusion of teachers into the operation of the school is beneficial for their emotional strength. This notion of a "democratic school" also implies the sharing of knowledge, and this implies not only knowledge about the school condition, but also about relevant research knowled or to consulting

Teachers are not adverse to educational strategies. Everton, Galton, and Pell (2000) and using it in their classroom teaching stracteg thers, that $96 \%$ said they had considfound, in their study of United Kingde at some point in their careers. Qualifications ered educational research know to be important factors in determining which teachand teaching experience seemed rearch findings; inexperienced teachers were less ers had considered educational research findings, which suggests that length of career expeing this practice. But what is interesting is rience may be an important factor regarding research findings, roughly $78 \%$ were that, of those who said they had consider project or research finding. The $22 \%$ who able to name at least one specific research project or qualifications or who had less could not do this were teachers withe These results are partly consistent with Bidthan 10 years of teaching experience. These findings regarding school principals, in which a large one research knowledge tradition. However number, about $98 \%$, could name at least on the Australians, it was those principals in the case of school principals, at least for the Ausher degrees who were the most who were younger and had recently completed hights that the conditions under which knowledgeable about research results. This suggests that the consult the findings of educaschool principals and school teachers reme circumstances. In either case, however, tional research, might be different in som another, educational research does reach practicing it seems clear that in one way or
educators, including teachers.

\section{Sources of Research Knowledge}

Given that education research is considered by teachers, the next question is how do teachers learn about it? The most obvious response to this question is through teacher magazines and other publications which relay education research in a way that practicing educators can understand. There is a wide rank of Education Digest, most countries which are oriented to teachers. One cancipal in the United States, The Phi Delta Kappan, Educational Leadership Australia, New Zealand Science Teachers Professional Educator and Teacher in Austand and Pedagogiska Magasinet in Sweden, Magazine in New Zealand, Teacher, Everton and his colleagues found, magazines and that teachers have for exposure to research knowledge. journals are only one source that courses, other professional journals, books, and Their respondents listed various al., 2000).

Once again, this finding is consistent with the findings of Biddle and Saha $(2002 / 2005)$ that the main sources of exposure to research come through profes(2002/2005) that the main sources of exposure to researsions. Thus teachers, esper
sional journals and bulletins, and then professional meetings.
cially those who have higher levels of qualifications, and more experience, do have 
adequate opportunity to learn about research and possibly incorporate it into their classroom practices. Everton and colleagues found that $49 \%$ of their teacher respondents said that exposure to research findings had caused them to improve their views about teaching and learning. However this does not mean that teachers understand the research, or that the various sources transmit it correctly. But teachers, and not just school principals, are often well-informed about research, and they use it.

A number of explanations have been put forward to document the greater dissemination of research knowledge, and indeed, to argue for the greater availability and accessibility of research knowledge. Thelwall (2002), for example, notes the increasing use of the Web as a means of disseminating research knowledge, which implies that other researchers and users actually are relying on the Web to find it. Although there are obvious cautions regarding the Web because of its unregulated nature, according to Thelwall it nevertheless has become a "primary means" of research knowledge dissemination (p. 413).

But information on the Web does not guarantee the motivation to seek research knowledge. After a review of the literature, Hemsley-Brown and Sharp (2003) suggest that the establishment of more effective communication networks between researchers and the educational practitioners may improve the desire for, and understanding of research, and to raise its credibility. A second suggestion, however, is that the teachers (and presumably school principals as well) should become more involved in the research process. This could mean several possibilities: (1) that educational practitioners become partners with, academic researchers, or (2) that educational practitioners themselves become researchers. It is this second possibility that will now be considered.

Teachers can generate their own research findings. It is not unusual for schools to develop their own research projects to resolve a highly specific problem or need. In fact, in recent years there has been a growth in both the literature and practice of teachers becoming researchers, or engaging in what is known as "action research" (Ponte, 2002; Wallace, 1998). However, as Biddle and Saha (2002/2005) found, this occurs primarily in schools with a larger number of teachers who have postgraduate training. When principals have a larger number of teachers with postgraduate qualifications, they are able to turn inwards for their source of new knowledge, that is, they generate this knowledge through their own in-school research projects. Thus, the higher the levels of qualifications of teachers, the more conducive is the intellectual climate of the school, and the more likely are the teachers able to take a more professional role in research (Saha et al., 1995). This finding is consistent with the argument that schools, in which teachers can play more professional roles, are likely to be successful schools (Chubb \& Moe, 1990; Peterson, 1990):

\section{Knowledge Versus Other Criteria for Becoming an "Expert" Teacher}

The focus on research knowledge as a source of teacher expertise assumes that the cognitive demands of teaching are the most important in determining teacher and sefiool quality. Indeed, it has been argued that a focus on the cognitive dimensions, 
namely teacher knowledge, teacher decision making and teacher reflection and dispositions were not only regarded as criteria for successful teachers, but also essential for teacher training programs (Grossman \& McDonald, 2008). However, more recently it has been argued that relational aspects of teaching as practice, namely teaching as a craft and as a way of relating to others, particuares questions about be taken into account (Grossman \& McDonald, 2008). This cognitive dimension of whether education research know role. It would appear not. Everton et al. found that teacher expertise and the teacher mowledge influenced teachers, "social and personal of the areas in which research know th ten areas listed (Everton et al., 2000). relationships" was listed as fourth out of the ten ar and Saha (2002/2005) who found Again, this is reflected in the findings of Bidd ant frequently recognized "teacher that both American and Australian principals morch area, and that "teacher morale expectations and student achievement" as a resement" were also recognized moderand retention" and "student and teacher me most "relational," in that they focus on the ately. Out of 20 areas, these three were classroom.

teachers' contacts with students in the can benefit all aspects of the role of the teacher. and principals (who were at one Therefore, the evidence from research on teachers and professional expertise, but it also time teachers), not only advances knowledge and professional expentacts with students, has an impact on the relational aspects of the

parents, and educational administrators.

\section{and Teachers}

A Global Perspective of Educational Research Knowledge

As already mentioned, educational research knowledge can be generated and used at a very local level, for example in individual schools, or at a broader academic or professional level. It is often assumed that research knowledge is system-specific or country-specific. However, as Biddle and Saha (2002/2005) dinch-related journals as research, many Australian school principals read ovout ideas which might assist them in part of their responsibility for keeping up was not the case for the American principals, running their own schools. Ironically, this was not the cessional proficiency. This examwho only read American sources to maintain their preducational research knowledge. ple raises a larger question about the global nature of education. The roles, expectations and

Teachers are increasingly a part of a global profess most countries of the world. Teachbehaviors of school teachers are pretty similar in most couts such as status, pay, workload, ers may differ considerably across countries in matters role remains very similar. This and resources, but the core nature of the tready in the 1970 s by Meyer et al. (1977) convergent phenomenon was recognized already in who argued that a world educational culture was eme Although some might argue that for the expansion of education throughout the wherely represents a dominant or hegem this world or global educational culture ultimately relating to educational structures and this world or global education
onic Western model, nevertheless in matters relating to educational structure 
be following the best developed and available model of schooling (Ramirez \& Boli, 1987; Meyer \& Kamens, 1992).

However, in addition to global models of the curriculum and school structures, there exists what some call global discourses of educational practices and policy. Along with these practices and policies is a body of knowledge which relates to a range of teacher behaviors, including pedagogies and classroom practices regarding the teaching of specific subjects. This global body of knowledge is even more complex, in that it relates to the links between schooling and economies, and also to the notion of lifelong education (Spring, 2008). This widespread notion applies not only to the preparation of students for an occupational history which will require the continual upgrading of skills and knowledge, but also to teachers who themselves must have their own pedagogical and relational knowledge and skills continually upgraded. Thus when we address questions about how teachers get exposed to, and acquire educational research knowledge about teaching, we need to consider the impact of global knowledge which has become a part of cultures and which "everybody knows," or at least they think they know. Whether educational research knowledge is transmitted through university courses, teacher magazines and journals, workshops and other forms of in-service training, the Web, or school principals themselves, a significant body of knowledge exists in an ever converging global culture.

\section{Conclusion: Teachers and Education Research Knowledge}

Teachers, by virtue of their classroom duties, are at the bottom of the educational hierarchical chain of professionals. They represent the coal-face of the education system, and are the point of contact with the clients of the educational system. Educational research knowledge, on the other hand, is normally produced by professional researchers in universities or similar institutions. The audience for educational research is traditionally other researchers and higher level educational administrators. It has long been argued that this is where the impact and relevance of educational research stops. For this reason, educational research has been thought to be useless and without value to the everyday life of the teacher or the school.

However, as demonstrated in this chapter, there is evidence that the findings of educational research reach the end of the hierarchical chain, namely the teachers. Teachers are exposed to various agents which transmit relevant findings to teachers. Because teachers are not always trained as professional researchers, it is therefore reasonable that these research findings must be transmitted in a form accessible to the untrained teacher to understand and to utilize it if relevant. Thus magazines, bulletins, journals and books are a main agent for of this dissemination process. However there are other agents. Teachers also attend workshops, seminars and conferences, and search the Web, and these also constitute avenues for the transmission of research knowledge. Teachers are not a homogeneous group, and as studies have shown, they vary conSiderably in qualifications and credentials. It has been disputed whether qualifications and credentials make a person a better and more effective teacher (Greene, 2005). However, it is apparently the case that teachers themselves, particularly those 
with postgraduate qualifications, are often producers of research knowledge. School principals, who have on their staff a large proportion of teachers with postgraduate qualifications, also are more able to generate their own research findings, and create a research climate in the school. This type of research knowledge, because it is focused and locally generated, is more likely to be relevant for the teachers in their own classrooms. On the other hand, this kind of research is less wider educational community. cumulative research findings which is accessible to the widy of both educational research Nonetheless, it is a

hers is sometimes research by teachers, and teachers

In the end, research on teachers in can be both consumers and producers of res in made increasingly accountable for the performance of all educational practition, it is important to give greater attention to the level of student academic percher community which has the knowledge and expertise possibilities of creating a teacher complex and diverse student body. In this respect, to solve the challenges of a more raise its profile and relevance for the education research knowledge will even migh quality functioning of educational systems.
high

\section{Biographical Note}

Lawrence $\mathbf{J}$. Saha is a sociologist of education with 30 years experience in teaching and research. He is Professor in the School of Social Sciences at the Australian National University and a former Dean of the Faculty of Arsemination of education educational research are social psychology of education, dissemith political socialization. research knowledge, education and devecion) and contributor for the International He was section editor (Sociology of Edition (Elsevier, 1994), and Editor of the InternaEncyclopedia of Education, 2nd edition (Elogy of Education (Elsevier, 1997). His most recent tional Encyclopedia of the Sociology of Education (Evearch Knowledge, and Policy works are The Untested Accusation: Principals Research Konn., 2002/2005pbk, with Making in Schools (Ablex Publishing Coricipation (co-editor, Sense Publishers, Bruce J. Biddle) and Youth and Political Participation (co-editor Sochology of Education: An International Journal (Springer).

\section{References}

5) The untested accusation: Principals, research knowledge, and policy making in schools. Westport, CT; Lanham, MD: Ablex Publishing and Scarecrow Education. iddle, B. J., \& Saha, L. J. (2006). How principals use research. Educational Leadership, 63 , The Brookings Chubb, J. E., \& Moe, Institution.

Daresh, J. C. (1998). Professional development for school leadership: The impact of U.S. educational . Procational Research, 29, 323--333.

reform. International Journal of Educational Research

Dworkin, A. G., Saha, L. J., \& Hill, A. N. (2003). Tearnal, 4, 108-120. environment. International Education Journal, 4,108 
Everton, T., Galton, M. \& Pell, T. (2000). Teachers' perspectives on educational research: Knowledge and context. Journal of Education for Teaching, 26, 167-182.

Finn, C. E., Jr. (1988). What ails education research? Educational Researcher, 17, 5-8.

Greene, J. P. (2005). Education myths. Lanham: Rowman \& Littlefield.

Grossman, P., \& McDonald, M. (2008). Back to the future: Directions for research in teaching and teacher education. American Educational Research Journal, 45,184-205.

Hallinger, P. (2003). School leadership development. In P. Keeves \& R. Watanabe (Eds.), International handbook of educational research in the Asia-Pacific region (Vol. 2, pp. 1001-1013). Dordrecht, the Netherlands: Kluwer Academic.

Hallinger, P. (1987). Principal instructional leadership management rating scale. Nashville, TN: Author.

Hemsley-Brown, J., \& Sharp, C. (2003). The use of research to improve professional practice: A systematic review of the literature. Oxford Review of Education, 29(4), 449-470.

Meyer, J. W., \& Kamens, D. (1992). Conclusion: Accounting for a world curriculum. In J. W. Meyer, D. Kamens, \& A. Benevot (Eds.), School knowledge for the masses: World models and national primary curricular categories for the twentieth century (pp. 165-179). Bristol, PA: Falmer Press.

Meyer, J. W. et al. (1977). The world education revolution. Sociology of Education, 50, 242-258.

O'Donnell, R. J., \& White, G. P. (2005). Within the accountability era: Principals' instructional leadership behaviors and student achievement. NASSP Bulletin, 89, 56-70.

Peterson, K. D. (1990). Effective school principals. In T. Husén \& T. N. Postlethwaite (Eds.), The international encyclopedia of education, Supplementary Volume Two (pp. 208-212). Oxford: Pergamon Press.

Petzko, P. N., Clark, D. C., Valentine, J. W., Hackman, D. G., Nori, J. R., \& Lucas, S. E. (2002). Leaders and leadership in middle level schools. NASSP Bulletin, 86, 3-15.

Ponte, P. (2002). How teachers become action researchers and how teacher educators become their facilitators. Educational Action Research, 10(3), 399-423.

Ramirez, F. O., \& Boli, J. (1987). The political construction of mass schooling: European origins and worldwide institutionalization. Sociology of Education, 60(1), 2-17.

Saha, L. J., \& Biddle, B. J. (2006). The innovative principal: Research in action. Principal, 85, 28-33.

Saha, L. J., Biddle, B. J., \& Anderson, D. S. (1995). Attitudes towards education research knowledge and policymaking among American and Australian school principals. International Journal of Educational Research, 23, 7-20.

Spring, J. (2008). Research on globalization and education. Review of Educational Research, 78(2), 330-363.

Sroufe; G. E. (1997). Improving the "awful reputation" of educational research. Educational Researcher, $26,26-28$

Thelwall, M. (2002). Research dissemination and invocation on the Web. Online Information Review, $26(6), 413-420$.

United States Congress (2002). No Child Left Behind Act of 2001. In H.R. 1 .

Wallace, M. J. (1998). Action research for language teachers. New York: Cambridge University Press. 